International Journal of English Literature and Social Sciences
Vol-6, Issue-2; Mar-Apr, 2021
Journal Home Page Available: $\underline{\text { https://ijels.com/ }}$
Journal DOI: $10.22161 /$ ijels

\title{
G. B. Shaw's War Antipathy in Arms and the Man and Major Barbara
}

\author{
Ghassan Awad Ibrahim¹, Prof. Dr. Mahmoud Ali Ahmed Omer ${ }^{2}$
}

${ }^{1} \mathrm{PhD}$ Student, Al-Turath University College, Iraq

${ }^{2}$ Supervisor, Sudan University of Science and Technology, Sudan

Received: 03 Jan 2021; Received in revised form: 26 Feb 2021; Accepted: 26 Mar 2021; Available online: 25 Apr 2021

(C)2021 The Author(s). Published by Infogain Publication. This is an open access article under the CC BY license

(https://creativecommons.org/licenses/by/4.0/).

\begin{abstract}
This research paper deals with George Bernard Shaw's treatment of wars and their warmongers whose intention is to urge or attempt as much as they can to stir up war which largely culminates in death, destruction and all kinds of evil not to mention social diseases such as poverty, ignorance, starvation, prostitution and the like. In Arms and the Man and Major Barbara, Shaw expresses by his own ideas his real feelings of hatred and hostility when he pours his poignant criticism against capitalists and war makers, including weapon dealers, who encourage people to start or join a war to achieve their personal interests. The purpose of Shaw in writing his aforementioned plays is to show people the real ugly face of the wicked forces whose capitalistic and insatiable greed are so profound that they only aspire to personal power so that people can amend their wrong ideas of war fascination. Shaw's ideas represent a revolution against those warmongers who cannot silence him so that no peoples worldwide are denied their right to peace and a life free from fear.
\end{abstract}

Keywords - Warmongers, Capitalists, War Makers, Weapon Dealers, War Fascination, Peace.

\section{INTRODUCTION}

A historical survey of literature enables us to find out an enormous amount of war disasters and fears which are immortalized in plays, novels and poems across ages. Since Homer's ancient Greek epic poem The Iliad, dealing with the Trojan War, probably the most famous ancient war over unfortunately a long and bloody history, war has been the most important and well-known theme of all types of literature, painting, film, music or other art forms across history. The majority of the literary works of the most Greek well-known dramatists such as Aeschylus, Sophocles and Euripides revolve around wars and their harmful psychological impacts not only on their victims but also on their winners. It is noteworthy that the famous Greek playwrights, mentioned above, are "combat veterans (Aeschylus and Sophocles were generals, Euripides also fought). The majority of their plays are about the effects of war on its victims and, equally, on its victors."1As far as Greek drama is concerned, the American playwright Karen Malpede whose writings are almost about social justice points out that "Greek drama shows us again and again that a decisive battlefield victory will also have a deleterious effect on the psyches of the heroes." ${ }^{2}$ The plays about the Trojan War show this grave effect not only on the war veterans but also on the people who are far away from it. Agamemnon which bears the name of its protagonist Agamemnon is the first of three linked tragedies that make up The Oresteia trilogy written by the ancient Greek playwright Aeschylus in the fifth century BC whose playwright was "ever the military man, when choosing how to immortalize himself, had written on his tombstone not that he was author of The Oresteia, and invented Greek Tragedy, but that he 'fought at the Battle of Marathon."'3Agamemnon deals with the harsh realities of war despite the returning of the Greek army from the Trojan War victorious. It shows how Agamemnon after returning home victorious from the Trojan War is murdered by his wife for his heinous act of slaying his daughter as a sacrifice presented to Apollo, a god in Greek mythology, to stir the wind so that the ships which carry warriors may move: "The general responsible for the victory at Troy, Agamemnon, is slain by his wife upon his return for the previous crime of having had his daughter slain as a sacrifice so the Greek ships might raise the 
winds to sail off to fight." ${ }^{4}$ The early beginning of the play starts with some lines sung by the chorus, explaining the worst impact of the real cruel and merciless nature of war not only on those who experience it but also on the peaceable people who are far away from it:

Chorus: They came back

To widows,

To fatherless children,

To screams, to sobbing.

The men came back,

As little clay jars,

Full of sharp cinders, war is a pawnbroker - not of your treasures

But of the lives of your men. Not of gold but of corpses.

Give your men to the war of God and you get ashes. ${ }^{5}$

Accordingly, a fact can be concluded that though classical dramatic plays deal with warriors, sacrifices and heroic aspects, they also speak about the harsh realities of war that inflict casualties on everyone in the warring countries, including children and women who suffer a lot from wars because "For Greek women, although they were not combat veterans, war is seen as equally corrupting; it steals children, turns women into chattel who are raped and sold, and ultimately changes the Greek Queen Clytemnestra and the Trojan Queen Hecuba into furious avengers," ${ }^{6}$ while the modern dramatic plays almost likewise, dealing with the aftermath of wars and their effects on both veterans and civilians. The Irish social satirist playwright George Bernard Shaw (1856-1950) is well known for his great hatred and hostility to war in general and its terrible consequences for the warring factions. His abhorrence to war and violence can be noted clearly before the outbreak of the First World War or the Great War (1914-1918) in some of his plays especially in Arms and the Man (1898)and Major Barbara (1905).

\section{DISCUSSION AND ANALYSIS}

By writing his two above-mentioned plays, Shaw in fact wants to warn people worldwide of the dangers of wars and those who feed on the blood of the warring sides, including Andrew Undershaft, who represents the economic and political system of capitalism. ${ }^{7}$ Undershaft, a main character in Shaw's Major Barbara, is proud of his job as a manufacturer of cannons and torpedoes which are designed and made to kill humanity because he has made his large fortune by selling weapons to warring factions, thus, he is like other manufacturers and weapons dealers becoming happy when a war erupts here and there on this earth so that their work would be prosperous and they become wealthier, providing their workers with jobs but forgetting the much death, bloodshed, suffering, pain and fear resulted from using their terrifying weapons by both fighting sides against each other to spread death, destruction, ruins, and all kinds of evil on this earth in addition to the terrible consequences of wars such as chaos, kidnapping, stealing, rape and displacement of innocent people and sometimes even the changing of the demography of the defeated countries. The British critic Alick West shows the opposite dualism of the personality of Undershaft who "has to represent in the first part of the scene the creative power of humanity and in the second part the power that destroys humanity for profit." 8

Furthermore, the manufacturers of weapons and arms dealers as well as war makers enjoy the atmosphere of luxury and wealth while the others suffer. In his foreword in Karen Malpede's Acts of War: Iraq and Afghanistan in Seven Plays, the American journalist and political analyst Chris Hedges (born 1956) whose writings are almost about social justice describes proficiently the evil intention of war makers by saying "Those who make war work overtime to reduce love to smut, and all human beings become objects, pawns to use or kill." ${ }^{9}$ For Undershaft and those who take advantages over the ordeals of others despise and criticize shamelessly religion and its instructions of ethics because religion does not conform to their wicked psyches, evil expectations and insatiable appetite for power. Apparently, Undershaft is a cruel and vicious man who does not express concern and regret about any immoral deed he might have done within the range of his business that provides him with a great wealth and enables him at the same time to lead a life of considerable luxury when he confesses personally and frankly that he feeds on the bloodshed of the killed or wounded people, including military personnel during wartime. The passage below sums up the real contemptuous psyche of Undershaft and the way of his thinking as he represents all evil individuals of his kind in the world who are very wicked by nature and take pleasure in doing things that harm other people to destroy life and property of them when he himself uncovers boldly and openly his most brutal characteristics:

The more destructive war becomes, the more fascinating we find it ... making the usual excuse for my trade; but I am not ashamed of it. I am not one of those men who keep their morals and their business in water - 
tight compartments. All the spare money my trade rivals spend on hospitals, cathedrals, and other receptacles for conscience money. I devote to experiments and researches in improved methods of destroying life and property. I have always done so; and I always shall. Therefore, your Christmas and moralities of peace on earth and goodness among men are of no use to me. Your Christianity, which enjoins you to resist not evil, and to turn the other cheek, would make me bankrupt. My morality - my religion- must have a place for cannons and torpedoes in it. ${ }^{8}$

Accordingly, Undershaft, just like his capitalist peers, who shamelessly makes confessions of his beliefs and real feelings is a very mean, rude and unkind person to other people. In this respect, Michael Savage (born 1942), an American author and radio presenter who is renowned for his political philosophy, relegates in his Stop Mass Hysteria (2018) people like undershaft to the low rank of a dirty animal when saying: "If you are a person who achieved some degree of financial success, you're a 'capitalist pig' who hates poor people"9

Moreover, Undershaft as a capitalist who runs a business in order to make a profit for himself, confirms the importance of gaining money and ammunitions as a principle in his life to justify his evil deeds when he convinces himself to "choose money and gunpowder; for without enough of both you cannot afford the others." ${ }^{10}$ In his preface to his play Heartbreak House (1919), Shaw protests against all wicked people who love war to achieve power and fame, feeding themselves on the blood of others when writing:

The cupidity of capitalists, the ambition of conquerors, the electioneering of demagogues, the Pharisaism of patriots, the lust and lies and rancors and bloodthirsts that love war because it opens their prison doors, and sets them in the thrones of power and popularity. For unless these things are mercilessly exposed they will hide under the mantle of the ideals on the stage as they do in real life."11

In fact, Shaw uses Undershaft who is a good example of the criminal figures in the world to show the real ugly face of such wicked and evil creature to be detested by the audiences. Evil Creatures such as Undershaft are samples taken from the real life to be depicted in the plays mentioned above as long as the concept of war is concerned so that they can directly arouse readers or spectators' thinking to hate and scorn Undershaft and all people of his kind for their vicious and bloody deeds and at the same time to make people amend unconsciously their wrong ideas especially about the fascination of war through Shaw's enlightening and constructive ideas and views over all those who contribute in wars industry. As a deeply compassionate man, Shaw expresses by his own words his strong feeling of dislike over the brutal deeds which are carried out by some wicked people for money and he simultaneously explains his belief in equality to achieve peace all over the world and to establish human values which stimulate individuals at any society to act in a kind and sympathetic way towards others, even towards people they do not agree with as he says:

As a humane person I detested
violence and slaughter,
whether in war, sport or the
butcher's yard. I was a socialist
detesting our anarchical
scramble for money, and
believing in equality as the
only possible permanent basis
of social organization,
discipline, subordination, good
manners, and selection of fit
persons for highfunctions. ${ }^{\mathbf{1 2}}$

By revealing his real feeling of hostility over all inhumane actions whether they occur in peace or war, Shaw is considered a pacifist and social reformer who establishes his meaningful and constructive ideas in a charming and pleasant manner in most of his writings because they are morally truthful and fit reasonably to change people for the better through convincing them of the universal human follies such as the fascination of war while watching or reading his plays by their own eyes to get rid of their wrong ideas because he believes that "The Theater is both school and church."13

Shaw's first two volumes plays collection entitled Plays Pleasant and Unpleasant (1898) have proved to be success in the English drama as they contain distinctive ideas aiming at correcting the wrong beliefs of people concerning almost all walks of life including the wrong 
belief of the fascination of war as shown in the Arms and the Man. The American critic and author A.C. Ward (1891-1973) elevates Shaw to the status of the ancient Greek thinker Socrates when he states that he "has been for modern Britain what Socrates was for ancient Greece."14 Besides, Shaw's literary achievements in drama gain the approval of Dr. Raghukul Tilak who describes Shaw's plays as a turning point in the "literary world" because:

Each of these plays proved a
veritable bombshell in the
literary world. They showed
that a new and powerful genius
had appeared on the dramatic
horizon whose main purpose
was to shake people out of
their social complacencies and
beliefs.
new dramatist was exploiting
with unusual effect the medium
of drama for shattering a
number of social, economic,
and political doctrines. The
dramatist was a combination of
the artist and the preacher. ${ }^{15}$

In his anti-war drama Arms and the Man (1894), Shaw humorously satirizes and attacks the conventional fascination of war, heroism and even patriotism when he has chosen a universal setting of the war that has occurred between the Balkans nations of Bulgaria and its neighbouring Serbia in 1885. In the play, Shaw focuses on romantic attractiveness more than war itself as the American professor William B. Irvine confirms that the play is not so much concerned with war but it concentrates on "the romantic attractiveness of war,"16 to show people the sheer follies of the fascination of war when he satirizes those who drum up public support for their interests when he makes the romantic character Catherine in the early beginning of the play is desperately eager to speed up the marriage of her daughter Raina to her fiancé, Major Sergius, when she goes impatiently as much as she can to tell Raina about the latest fake victory of their Bulgarian cavalry charge which has been led by Sergius, against Serbia, saying excitedly "Such news! There has been a battle.... A great battle at Slivnitza! A victory! And it was won by Sergius." ${ }^{17}$ Moreover, Catherine shows her a great admiration at Sergius' some gravely and deadly mistakes, considering him a hero who "defied our Russian commanders - acted without orders- led a charge on his own responsibility- headed it himself-was the first man to sweep through their guns." (G.B. Shaw, Arms and the Manp.16).
In the play, Shaw also pours a great deal of satire on military leaders when he ridicules the wrong decisions of some of them such as Sergius who has achieved victory against the enemy on the wrong military way when his irritable horse runs unpredictably towards the enemy lines (the Serbs), and the terrified Sergius cannot control it, thus he is the first to appear in front of the opposing soldiers who cannot kill neither him nor his soldiers who are following him because they have "wrong ammunition."(p.27) By striking the aforementioned example, Shaw intends to say that war is void of heroism. In his own point of view, Hedges believes that "War exposes the lies we tell ourselves about ourselves. It rips open the hypocrisy of our religions and secular institutions. Those who return from war have learned something which is often incomprehensible to those who have stayed home. ${ }^{18}$ In order to wake up the heroine Raina from her disillusionment, Shaw makes his protagonist captain Bluntschli, the fugitive mercenary soldier, confirms to Raina that Sergius's action is a logically wrong because he has exposed himself and his regiment to the risk of a genocide and therefore he deserves to be prosecuted in a military court instead of praising him by Catherine and Rhina especially the latter who immediately after hearing her mother's good news as they think, considering "That Sergius is just as splendid and noble as he looks! That the world is really a glorious world for women who can see its glory and men who can act its romance! What happiness! What unspeakable fulfillment."(PP.17-18).In fact, Raina just like her mother is a romantic character because she is a dreamer when she expresses her greatest admiration for Sergius while looking at the portrait of her fiancé in her upstairs room, murmuring "My hero! my hero!" (P.19) describing him falsely as "the bravest of the brave!" (P.27).

Eventually, everything is revealed by Bluntschli who accidentally has joined the Serbian troops and later escaped terrified from the front line because he realizes that war is futile and there is no point in engaging in it, especially when the Serbian troops have fake ammunition. Hedges state firmly that war "is neither glorious nor noble. And we carry within us the capacity for evil we ascribe to those we fight." ${ }^{19}$ Escaping from the battlefield, Bluntscli hides himself, by chance, in Raina's bedroom so that he cannot be found by the Bulgarian soldiers who are chasing after him. In fact, Bluntschli's entering into Raina's bedroom unwittingly represents a romantic action and cooperation between people during war despite that he in reality is considered an enemy for Raina who has not only received, fed and protected him but also she helps him in the recovery of his wound "So the hero enters, wounded and exhausted, and is concealed by the heroine and saved 
from the pursuing soldiers of her own nationality. He represents the true romance. ${ }^{20}$ Raina is disillusioned with the victory of Sergius by Bluntschli who initially tells her about the horror of the battlefield and then expresses to her his own disgust at the obtuseness and stupidity of Sergius without knowing that the latter is her fiancé, saying:

And there was Don Quixote
(Sergius) Flourishing like a drum
major, thinking he'd done the
cleverest thing ever known,
whereas he ought to be
courtmartialled for it. Of all the
fools ever let loose on a field of
battle, that man must be the very
maddest. He and his regiment
simply committed suicide; only
the pistol missed fire: that's all.
(p.28).

As long as Sergius' alleged patriotic and heroic victory is concerned, Bluntschli who is fairly realistic and reasonable tells Raina as a seasoned mercenary soldier what exactly happens in the battlefield, describing the surge of Surgius and the soldiers who follow him towards the enemy's front line as "a funny sight. It's like slinging a handful of peas against a window pane: first one comes: then two or three close behind him, and then all the rest in a lump"(p.27). Furthermore, Bluntschli asserts to Raina that Sergius is not a hero and he does not intend to launch an attack against the foe when he proceeds to say that: "You should see the poor devil pulling at his horse .... It's running away with him, of course: do you suppose the fellow wants to get there before the others and be killed." (p.27).

Arms and the Manis regarded as a portrayal of the idea that the traditional romantic thinking about war and its heroism and fascination is something delusive and ridiculous. Throughout the events of the play, Shaw attacks the illusions of heroism, romance and fascination of war, demanding people indirectly to believe that there is no room for their illusions in wartime and people should not glorify war because the latter usually is almost immoral resulted in all the wicked and bad things that happen to the people of the warring countries. Accordingly, Tilak concludes that Shaw is a man of peace who hates war and recommends people to see the real ugly face of it in which there is no place for glorification and bravery but only bloodshed, destruction and a terrible loss of human life or as in Tilak's remark". It should be noted that though Shaw is a pacifist, he is opposed not so much to war as to the so called glorification of war. He argues that people should not weave a romantic halo round it, but know its grim and ugly truth. It is not an occasion for the display of valour or any other noble qualities."21

Additionally, in Shaw's words recited at the end of the play by his character Sergius after being disillusioned when he criticizes severely the real behaviour of a soldier in the war which lacks of mercy towards weak people by saying that "Soldiering is the coward's art of attacking mercilessly when you are strong, and keeping out of harm's way when you are weak."22Besides, Sergius as a military man is convinced that his personal conduct concerning his accidental triumph without taking orders from his leaders is wrong when he reveals that "I won the battle the wrong way when our worth Russian generals were losing it the right way. In short, I upset their plans, and wounded their self-esteem."(p.41).However, Raina's suspicions over the bravery and soldiership of Sergius come true when she unfolds to her mother in the beginning of the play her real feelings towards him, wishing that her doubts would be just an illusion "I doubted him: I wondered whether all his heroic qualities and his soldiership might not prove mere imagination when he went into a real battle". (P.17).Besides, Raina's thoughts over Sergius' military achievements in the battlefield in addition to the patriotism and heroic ideals of their country are nothing but dreams as she discloses that "Our ideas of what Sergius would do. Our patriotism. Our heroic ideals. I sometimes used to doubt whether they were anything but dreams. (P.17).

\section{CONCLUSION}

Throughout his lifetime, Shaw witnesses traumatic and bloody events when he survives the two destructive and disastrous World Wars that naturally make him a war-hater or in Tilak's words when he describes Shaw as a "pro-war and against war; he is pro-democracy and against parliament, pro-evolution and counter-Darwin, pronationalism and counter-patriotism." ${ }^{23}$ The author T. F. Evans shows his point of view over the prosecution of war as it is argued by Shaw himself in his writings, thinking that Shaw is an anti-war playwright as "he threw himself with great energy into public argument about how the war should be prosecuted, and this led to inaccurate assumptions that he was opposed to the war." ${ }^{24}$ Shaw is a remarkable playwright when he makes the sense of pride of Serjius's supposed victory told by Catherine juxtaposes with the traumatic truth told by Bluntschli to make his audiences aware of the wars risks and to make them amend their wrong ideas over heroism resulted from war as they think when he presents his ideas to his audiences in a satiric way in which humour and exaggeration are used by the playwright to criticize what he thinks is wrong in the society including the wrong ideas of the readers or the 
audiences themselves. Besides, He expresses frankly his true point of view over his comic plays, saying "When a comedy is performed, it is nothing to me that the spectators laugh: any fool can make an audience laugh. I want to see how many of them, laughing or grave, are in the melting mood."25It is noteworthy that Shaw himself makes it clear that his attacks over social evils are not directed against the stages characters but against the spectators and readers themselves when he says: "I must, however, warn my readers that my attacks are directed against themselves, not against my stage figures." ${ }^{26}$ Hedges criticizes explicitly his American society, accusing it of hypocrisy when writing "We, as a nation, prefer to listen to those who speak from the patriotic script. We prefer to hear ourselves exalted. If veterans speak of terrible wounds visible and invisible, of lies told to make them kill, of evil committed in our name, we fill our ears with wax." ${ }^{27}$ However, Shaw's attacks become fruitful when they affect positively the audiences at that time who have sought theatres for entertainment as he reveals in an essay that "I myself have been told by people that the reading of a single book of mine or witnessing of a single play has changed their whole lives." ${ }^{28}$ The remarkable interior changes in English social life after the Great War have increased the antipathy of not only the English playwrights but also the English audiences towards wars as they have sought theatres to forget at least the traumas and agonies of wars. Like Shaw, the English playwright Robert Cedric Sherriff (1896-1975) writes his masterpiece Journey's End in 1928 which is an anti-war drama as it has reflected brilliantly the scenes of misery and degradation of the Great War. Sherriff's play is regarded as a big landmark in the English drama as it has added an interest to the English people and taken up all their attention at that time or in the words of the British writer and critic William Aubrey Darlington (1890-1979) when he has described the play as "one of the most completely absorbing plays ever written."29

\section{REFERENCES}

[1] Karen Malpede et al: Acts of War, Iraq and Afghanistan in Seven Plays (United States of America; Northwestern University Press 2011), p. xv.

[2] Ibid, p. xv.

[3] Karen Malpede et al: Acts of War, Iraq and Afghanistan in Seven Plays (United States of America; Northwestern University Press 2011), xxiv.

[4] Karen Malpede et al: Acts of War, Iraq and Afghanistan in Seven Plays (United States of America; Northwestern University Press 2011), xv.

[5] Aeschylus, The Oresteia, Ted Hughes (trans), Faber, London 1999. p.24.
[6] Karen Malpede et al: Acts of War, Iraq and Afghanistan in Seven Plays (United States of America; Northwestern University Press 2011), p. xv.

[7] According to Collins Cobuild Dictionary on CD-ROM 2006 capitalism is an economic and political system in which property, business, and industry are owned by private individuals and not by the state.

[8] Alick West, A Good Man Falling Among Fabians: A Study of George Bernard Shaw (London: Lawrence and Wishhart LTD, 1974), P. 140.

[9] Chris Hedges as quoted in Karen Malpede et al: Acts of War, Iraq and Afghanistan in Seven Plays (United States of America; Northwestern University Press 2011), p. viii.

[10] George Bernard Shaw: Major Barbara, ed., by RaghukulTilak, edited with Critical introduction, Complete Text with paraphrases, Critical Reviews of the play, Critical and Explanatory Comments, and Select Literary Criticism (New Delhi: Rama Brothers India PVT. LTD., 2009), P. 156. All subsequent textual quotations are taken from this reference.

[11] Bernard Shaw, Heartbreak House, Great Vatherine, Playlets of the War, Brentano's, New York 1919, liv.

[12] George Bernard Shaw, "Preface: Mainly about Myself," in George Bernard Shaw, Plays Unpleasant (Reading, G.B.: Cox \& Wyman, Ltd. 1981). P.7.

[13] George Bernard Shaw, "Preface to Plays Pleasant," in George Bernard Shaw, Arms and the Man (London: Longman Group Ltd., 1973). P.7.

[14] A.C. Ward, as quoted in Tilak, edited with Critical introduction, Complete Text with paraphrases, Critical Reviews of the play, Critical and Explanatory Comments, and Select Literary Criticism (New Delhi: Rama Brothers India PVT. LTD., 2009), p.9.

[15] RaghukulTilak, Bernard Shaw: Arms and the Man, 21st.ed. (New Delhi: Rama Brothers India PVT. Ltd. Educational publishers, 2009), p.3.

[16] William Irvine, The Universe of G.B.S. (New York: McGraw-Hill Book Company, Inc. 1949) p.171.

[17] RaghukulTilak, Bernard Shaw: Arms and the Man, $21^{\text {st }}$.ed. (NewDelhi: Rama Brothers India PVT.Ltd. Educational publishers, 2009), p.3.

[18] Hedges as quoted in Karen Malpede et al: Acts of War, Iraq and Afghanistan in Seven Plays, p. vii.

[19] Ibid. p. vii.

[20] Coles Editorial Board, The works of G. B. Shaw (Toronto: Coles Publishing Company Limited, 1980), p.33.

[21] RaghukulTilak, Bernard Shaw: Arms and the Man, p.23.

[22] Ibid, p.23.

[23] Ibid. p, 23.

[24] T. V. Evans, ed., Shaw: The Critical Heritage (London: Routledge\&Kegan Paul, 1976), p.15.

[25] George Bernard Shaw, "Preface to Plays Pleasant," in George Bernard Shaw, Arms and the Man (London: Longman Group Ltd., 1973). P.7.George Bernard Shaw, "Preface to Plays Pleasant," in George Bernard Shaw, Arms and the Man (London: Longman Group Ltd., 1973). P.7. 
[26] G.B. Shaw, "Preface: Mainly about Myself," p.27.

[27] Karen Malpede et al: Acts of War, Iraq and Afghanistan in Seven Plays, pp. vii-viii.

[28] Bernard Shaw, "The Quintessence of Ibsenism," in (noauthor) The Idea of Literature: The Foundations of English Criticism (Moscow: Progress Publishers, 1979), p. 15 .

[29] William Aubrey Darlington, Six Thousand and One Nights, Harrap, London 1960, p.154. 